ACTA UNIVERSITATIS NICOLAI COPER NICI DOI: http://dx.doi.org/10.12775/AUNC_ECON.2014.005 EKONOMIA XLV nr 1 (2014) 83-98

Pierwsza wersja złożona 14 października 2013

ISSN

Końcowa wersja zaakceptowana 15 czerwca 2014

2080-0339

\title{
Katarzyna Cheba*
}

\section{PRZESTRZENNO-CZASOWE MODELOWANIE POZIOMU ŻYCIA MIESZKAŃCÓW MIAST POLSKI***}

$\mathrm{Z}$ a r y s t r e ś c i. W literaturze przedmiotu stosunkowo mało jest informacji na temat przestrzennego zróżnicowania poziomu życia w miastach, w szczególności w miastach mniejszych. W pracy podjęto próbę analizy przestrzennego zróżnicowania poziomu życia mieszkańców miast na prawach powiatu w ujęciu dynamicznym w latach 2002-2011. Uwzględnienie czasu $\mathrm{w}$ badaniach przestrzennego zróżnicowania poziomu życia pozwoliło, dzięki możliwości wykorzystania metod analizy szeregów czasowych, na wyodrębnienie miast, w których można zaobserwować poprawę warunków życia, miast o stałym poziomie oraz tych, dla których następuje pogarszanie się poziomu życia.

S łow a kluczowe: modelowanie przestrzenno-czasowe, analiza dynamiczna, rozwój miast.

K 1 a s y fik a c j J E L: C5, R1.

\section{WSTEP}

Miasta będące obszarami o największej zdolności do kreowania wzrostu gospodarczego odgrywają coraz istotniejszą rolę $\mathrm{w}$ prowadzeniu polityki rozwoju zarówno na poziomie krajowym, jak i europejskim. Jednym z efektów rozwoju gospodarczego i społecznego współczesnego świata, globalizacji oraz integracji gospodarczej są znaczne różnice w poziomie rozwoju

\footnotetext{
* Adres do korespondencji: Katarzyna Cheba, Zachodniopomorski Uniwersytet Technologiczny w Szczecinie, WE, ul. Janickiego 31, 71-270 Szczecin, e-mail: katarzyna.cheba@zut.edu.pl.

** Badania zrealizowane w ramach pracy naukowej finansowanej ze środków na naukę w latach 2010-2013 jako projekt badawczy.

(C) 2014 Uniwersytet Mikołaja Kopernika. All rights reserved. http://www.aunc.ekonomia.umk.pl
} 
miast, obserwowane również w Polsce. Obok procesów związanych ze wzrostem miast, głównie dużych metropolii, widoczne są również tendencje odwrotne związane z depopulacją, czyli utratą zasobów ludzkich, charakterystyczne bardzo często dla mniejszych ośrodków np. miast średniej wielkości.

Wyrazem zainteresowania rozwojem miast polityków oraz praktyków gospodarczych są zapisy zarówno polityki przestrzennej kraju określonej w Koncepcji Przestrzennego Zagospodarowania Kraju 2030 (KPZK 2030), jak i polityki regionalnej, która jest definiowana w Krajowej Strategii Rozwoju Regionalnego 2010-2020. Dokumenty te zawierają ramy dla prowadzenia polityki rozwoju miast na poziomie krajowym i regionalnym oraz lokalnym (Wojciechowski, 2013). Badaniu rozwoju dużych aglomeracji miejskich poświęcono, jak do tej pory, sporo miejsca w literaturze przedmiotu (Gerőhazi, Hegedus, 2011, Mallach, 2010, Herbst, 2009, Parysek, 2005, Berry, 1981). Znacznie mniej jest natomiast informacji na temat przestrzennego zróżnicowania poziomu życia w miastach mniejszych, np. średniej wielkości, a także analiz porównawczych dotyczących rozwoju dużych aglomeracji miejskich oraz mniejszych ośrodków miejskich. Celem pracy jest analiza przestrzennego zróżnicowania poziomu życia mieszkańców dużych miast powiatowych (powyżej 150 tys. mieszkańców) oraz miast średniej wielkości (od 50 do 150 tys. mieszkańców), przeprowadzona na podstawie danych z lat 2002-2011.

Aby zweryfikować tak postawiony cel badania (analiza porównawcza rozwoju poziomu życia w ujęciu dynamicznym), przyjęto następujące tezy badawcze:

1. Istnieją znaczne różnice w tempie i kierunkach rozwoju poziomu życia mieszkańców miast średniej wielkości (od 50 do 150 tys. mieszkańców) oraz mieszkańców dużych miast na prawach powiatu (powyżej 150 tys. mieszkańców).

2. Uwzględnienie czasu w badaniach przestrzennego zróżnicowania poziomu życia mieszkańców miast $\mathrm{z}$ wykorzystaniem taksonomicznego miernika rozwoju daje podstawy do wskazania obszarów (dziedzin), w których można zaobserwować poprawę warunków życia, obszarów, w których nie będą następowały zmiany, oraz tych, dla których będzie następować pogarszanie się poziomu rozwoju.

Badanie przestrzennego zróżnicowania poziomu życia mieszkańców średnich miast jest częścią projektu finansowanego ze środków na naukę w latach 2010-2013 pt. „Model referencyjny logistyki miejskiej a jakość życia mieszkańców". Natomiast celem analizy poziomu życia mieszkańców dużych miast było porównanie kierunków oraz tempa zmian tego po- 
ziomu w stosunku do wyników dotyczących miast średnich przedstawionych w pracy Cheby (2010).

\section{OPIS DANYCH I ZASTOSOWANA METODA BADAWCZA}

Badania przeprowadzono na próbie obejmującej miasta na prawach powiatu zróżnicowane pod względem wielkości, w tym 23 duże miasta o liczbie mieszkańców powyżej 150 tys. oraz 36 miast średniej wielkości (od 50 do 150 tys. mieszkańców).

$\mathrm{W}$ ramach przeprowadzonych badań analizie poddano ten sam zestaw cech, który rozpatrywano w odniesieniu do mieszkańców miast średniej wielkości oraz dużych (powyżej 150 tys. mieszkańców). Zbiór analizowanych zmiennych obejmował dostępne informacje statystyczne dotyczące siedmiu rozpatrywanych obszarów (dziedzin). Utworzony bank danych zawierał 45 cech diagnostycznych opisujących różne obszary poziomu życia, natomiast do finalnego zbioru wytypowano 19 zmiennych. Do wyboru reprezentantów poszczególnych obszarów zastosowano metodę parametryczną Hellwiga (1981). Po wyznaczeniu macierzy współczynników korelacji pomiędzy poszczególnymi zmiennymi należącymi do wyodrębnionych obszarów, dokonano podziału wszystkich zmiennych na dziedziny zawierające zmienne centralne wraz ze zmiennymi satelitarnymi oraz tzw. zmienne izolowane. Dobór zmiennych przeprowadzono dla wszystkich analizowanych lat. Ostateczny zbiór zmiennych utworzyły te cechy (centralne i izolowane), których częstotliwość występowania w całym analizowanym okresie była największa, reprezentujące wszystkie wyodrębnione obszary, charakteryzujące się wysoką zmiennością przestrzenną, o niskim skorelowaniu $w$ ramach wyodrębnionych dziedzin $\mathrm{i}$ asymetrycznym rozkładzie (Zeliaś i in., 2000).

Ze względu na bardzo wysoką zmienność (Vs > 100\%) oraz pośredni wpływ na poziom życia mieszkańców miast zaproponowano wyłączenie z ostatecznego zbioru zmiennych cech opisujących stopień zanieczyszczenia środowiska naturalnego. Jak wykazano w pracach (Zeliaś i in., 2000; Cheba, 2010), zbyt duże przestrzenne zróżnicowanie wskaźników $\mathrm{z}$ tego obszaru oraz relatywnie duży udział w zmienności miary syntetycznej powoduje, że miasta należące do obszarów, dla których wskaźnik ten jest najniższy (np. ze względu na niski stopień uprzemysłowienia), osiągają znacznie wyższe wartości wykorzystanego w badaniach miernika syntetycznego. Z kolei tak wysokich wartości tego miernika rozwoju nie odnotowuje się dla tych miast w przypadku wszystkich pozostałych obszarów uwzględnionych w badaniu. 
Do ostatecznego zbioru zmiennych diagnostycznych, który stał się podstawą do dalszych badań empirycznych, zakwalifikowano następujący zestaw cech:

- ochrona zdrowia: $x_{1}$ - śmiertelność niemowląt na 1000 urodzeń żywych, $\mathrm{x}_{2}$ - liczba zgonów na 1000 osób, $\mathrm{x}_{3}$ - liczba zgonów w wieku 1-59 lat na 1000 osób, $\mathrm{x}_{4}$ - liczba lekarzy dentystów na 10 tys. osób,

- rynek pracy, warunki i bezpieczeństwo pracy: $\mathrm{x}_{5}$ - liczba bezrobotnych zarejestrowanych na jedną ofertę pracy, $\mathrm{x}_{6}$ - liczba poszkodowanych w wypadkach przy pracy na 1000 pracujących, $\mathrm{x}_{7}$ - liczba pracowników zatrudnionych $\mathrm{w}$ warunkach zagrożenia $\mathrm{zw}$. $\mathrm{z}$ uciążliwością pracy na 1000 zatrudnionych, $\mathrm{x}_{8}$ - podmioty zarejestrowane $\mathrm{w}$ rejestrze REGON na 10 tys. ludności,

- wynagrodzenia i dochody ludności: $\mathrm{x}_{9}$ - dochody budżetu miasta ogółem na 1 mieszkańca $\mathrm{w}$ zł, $\mathrm{x}_{10}$ - nakłady inwestycyjne przedsiębiorstw na 1 mieszkańca w zł, $\mathrm{x}_{11}$ - produkcja sprzedana przemysłu na 1 mieszkańca (1. prac powyżej 9 osób),

- warunki mieszkaniowe: $\mathrm{x}_{12}$ - przeciętna powierzchnia mieszkania $\mathrm{w} \mathrm{m}^{2}$ na 1 osobę, $\mathrm{x}_{13}$ - mieszkania wyposażone w $\mathrm{CO}$ w \% ogółu mieszkań zamieszkanych, $\mathrm{x}_{14}$ - mieszkania wyposażone w gaz w \% ogółu mieszkań zamieszkanych,

- oświata i edukacja: $\mathrm{x}_{15}$ - liczba dzieci w wieku 3-6 lat na 100 miejsc w placówkach wychowania przedszkolnego, $\mathrm{x}_{16}$ - przeciętna liczba uczniów na 1 oddział w szkołach podstawowych,

- kultura i czas wolny: $\mathrm{x}_{17}$ - czytelnicy bibliotek publicznych na 1000 osób,

- komunikacja i łączność: $\mathrm{x}_{18}$ - \% wydatki ogółem na transport i łączność w wydatkach ogółem; $x_{19}$ - drogi publiczne o twardej nawierzchni na $100 \mathrm{~km}^{2} \mathrm{w} \mathrm{km}$.

Wyodrębnione zmienne stały się podstawą umożliwiającą porównanie oraz klasyfikację badanych jednostek przestrzennych (miast) na grupy o podobnym poziomie życia. Do porównania przestrzennego zróżnicowania poziomu życia mieszkańców miast zastosowano taksonomiczny miernik rozwoju $z_{i}$, wyznaczony w oparciu o zmienne ujednolicone przez przekształcenie destymulant $x_{i j}^{\{D\}} \mathrm{w}$ stymulanty $x_{i j}^{\{S\}}$ na podstawie wzorów (Zeliaś i in., 1991):

$$
z_{i}=\frac{1}{r} \sum_{q=1}^{r} z_{i q} \quad(i=1, \ldots, m \quad q=1, \ldots, r)
$$


gdzie $r$ - liczba obszarów (dziedzin).

$$
x_{i j}^{\{S\}}=2 \bar{x}_{j}-x_{i j}^{\{D\}} \quad(i=1, \ldots, m \quad j=1, \ldots, k)
$$

gdzie $\bar{x}_{j}$ - średnia obliczona dla 23 lub 36 analizowanych miast w roku $t$ dla $j$-tej zmiennej, $S$ - zmienna stymulanta, $D$ - zmienna destymulanta.

Przyjęte przekształcenie pozwala na zachowanie średniego poziomu i zmienności zmiennej $\mathrm{w}$ jednostce czasu $t=1$, dodatkową zaletą tego sposobu przekształcenia jest możliwość pojawienia się wartości ujemnych, które w przypadku stymulanty oznaczać będą bardzo niekorzystną sytuację dla badanego obiektu (Zeliaś i in., 1991). Przekształceń destymulant w stymulanty, w kolejnych jednostkach czasu $t=2, \ldots, 10$, dokonano w oparciu o stałą wartość z jednostki czasu $t=1$. W ramach badań zastosowano normalizację zmiennych przez ustalenie punktu odniesienia (wartość maksymalna w kolejnych analizowanych latach), zgodnie ze wzorem (Grabiński i in., 1983):

$$
z_{i}=\frac{x_{i j}}{\max _{i=1, \ldots,, m}\left\{x_{j i t}\right\}} \quad(j=1, \ldots, k ; t=1, \ldots, n)
$$

gdzie $x_{j i t}$ - wartość zmiennej $x_{j}$ dla miasta $i$ w roku $t$.

Badania przeprowadzono w ujęciu dynamicznym dla wszystkich analizowanych lat. Uwzględnienie czasu $w$ badaniach przestrzennego zróżnicowania poziomu życia pozwoliło, dzięki możliwości wykorzystania metod analizy szeregów czasowych, na wyodrębnienie miast, w których można zaobserwować poprawę warunków życia, miast o stałym poziomie oraz tych, dla których następuje pogarszanie się poziomu życia (Zeliaś i in., 2004). W wyniku przyjętego sposobu przekształcenia analizowane zmienne mierzone są na skali przedziałowej. W związku z tym analizę dynamiczną przeprowadzono z wykorzystaniem metod, które można stosować w przypadku tego typu skal (Walesiak, 1999; Jajuga, 1993). Analiza dynamiki została przeprowadzona przy użyciu bezwzględnych przyrostów łańcuchowych na podstawie wzoru (Zeliaś i in., 2000):

$$
\Delta_{q i(t+1, t)}=z_{q i t+1}-z_{q i t}
$$

gdzie $(q=1, \ldots, 7 ; i=1, \ldots, 23$ lub $36 ; t=1, \ldots, 10), \Delta_{q i(t+1, t)}-$ przyrost bezwzględny łańcuchowy zmiennej syntetycznej $Z_{q}$ dla obiektu $i$ obliczony dla jednostek czasu $t$ i $t+1$. 
Następnie wyznaczono średnie tempo zmian w czasie na podstawie wzoru:

$$
G_{q i}=\frac{z_{q i 10}-z_{q i 1}}{9}(q=1, \ldots, 7 ; i=1, \ldots, 23 \text { lub } 36)
$$

gdzie $G_{q i}$ - średnie tempo zmian zmiennej syntetycznej $Z_{q}$ dla obiektu $i$.

\section{ANALIZA PORÓWNAWCZA ZMIENNYCH SYNTETYCZNYCH OPISUJĄCYCH POZIOM ŻYCIA MIESZKAŃCÓW MIAST}

Porównanie charakterystyk opisowych średniego tempa zmian zmiennych syntetycznych opisujących siedem grup mierników poziomu życia wyznaczone na podstawie informacji statystycznych z lat 2002-2011 dla 36 miast średniej wielkości oraz 23 dużych miast przedstawiono w tabeli 1.

Tabela 1. Charakterystyki opisowe średniego tempa zmian zmiennych syntetycznych w latach 2002-2011

\begin{tabular}{|c|c|c|c|c|c|c|c|}
\hline \multirow{2}{*}{ Charakterystyki opisowe } & \multicolumn{7}{|c|}{ Średnie tempo zmian - miasta średniej wielkości } \\
\hline & $\mathrm{G}_{1 i}$ & $G_{2 i}$ & $G_{3 i}$ & $G_{4 i}$ & $G_{5 i}$ & $G_{6 i}$ & $G_{7 i}$ \\
\hline Średnia arytmetyczna & 0,007 & 0,012 & $-0,009$ & $-0,017$ & $-0,021$ & $-0,047$ & $-0,065$ \\
\hline Odchylenie standardowe & 0,009 & 0,028 & 0,008 & 0,003 & 0,011 & 0,023 & 0,026 \\
\hline Mediana & 0,008 & 0,008 & $-0,010$ & $-0,018$ & $-0,023$ & $-0,049$ & $-0,062$ \\
\hline Maksimum & 0,032 & 0,137 & 0,013 & $-0,010$ & 0,001 & 0,009 & $-0,022$ \\
\hline Minimum & $-0,008$ & $-0,040$ & $-0,022$ & $-0,020$ & $-0,047$ & $-0,105$ & $-0,142$ \\
\hline \multirow{2}{*}{ Charakterystyki opisowe } & \multicolumn{7}{|c|}{ Średnie tempo zmian - miasta duże } \\
\hline & $\mathrm{G}_{1 i}$ & $\mathrm{G}_{2 i}{ }^{\prime}$ & $\mathrm{G}_{3 i}$ & $\mathrm{G}_{4 i}{ }^{\prime}$ & $\mathrm{G}_{5 i}$ & $G_{6 i}$ & $\mathrm{G}_{7 i}^{\prime}$ \\
\hline Średnia arytmetyczna & 0,004 & 0,016 & $-0,006$ & $-0,001$ & 0,001 & 0,001 & 0,019 \\
\hline Odchylenie standardowe & 0,010 & 0,024 & 0,008 & 0,001 & 0,008 & 0,013 & 0,013 \\
\hline Mediana & 0,002 & 0,008 & $-0,007$ & $-0,001$ & $-0,001$ & $-0,001$ & 0,017 \\
\hline Maksimum & 0,031 & 0,099 & 0,012 & 0,001 & 0,023 & 0,033 & 0,042 \\
\hline Minimum & $-0,010$ & $-0,006$ & $-0,021$ & $-0,003$ & $-0,020$ & $-0,016$ & $-0,011$ \\
\hline
\end{tabular}

Źródło: obliczenia własne.

Średnie tempo zmian wyznaczone na podstawie danych z lat 2002-2011 dla większości analizowanych obszarów, zarówno w przypadku miast średniej wielkości, jak i dużych, charakteryzuje się asymetrią prawostronną. Wartości mediany niższe od średniej arytmetycznej oznaczają, że większa liczba miast osiągała $\mathrm{w}$ analizowanym okresie niższe tempo rozwoju niż średnia. Sytuacja ta dotyczy następujących obszarów:

- miasta średniej wielkości: rynek pracy, warunki i bezpieczeństwo pracy, wynagrodzenia i dochody ludności, warunki mieszkaniowe, oświata i edukacja, kultura i czas wolny, 
- duże miasta: ochrona zdrowia, rynek pracy, warunki i bezpieczeństwo pracy, oświata i edukacja, kultura i czas wolny, komunikacja i łączność.

Do miast, dla których nastąpiła poprawa w pierwszym analizowanym obszarze dotyczącym ochrony zdrowia $\mathrm{w}$ stosunku do zmieniającego się maksymalnego poziomu w latach 2002-2011 (dodatnie średnie tempo zmian zmiennej syntetycznej), zaklasyfikowano 28 z 36 analizowanych miast średniej wielkości (ok. 78\%) oraz 14 z 23 miast dużych (ok. 61\%). Ujemne tempo zmian zaobserwowano w przypadku ośmiu miast średniej wielkości, są to: Słupsk $(-0,0077)$, Dąbrowa Górnicza $(-0,0060)$, Mysłowice $(-0,0056)$, Tychy $(-0,0051)$, Przemyśl $(-0,0037)$, Elbląg $(-0,0013)$, Żory $(-0,0006)$, Rybnik (-0,0003). Natomiast w przypadku dużych miast ujemne tempo dotyczyło takich miast jak: Katowice $(-0,0095)$, Olsztyn $(-0,0063)$, Gliwice $(-0,0062)$, Gdynia $(-0,0056)$, Częstochowa $(-0,0045)$, Szczecin $(-0,0016)$, Poznań $(-0,0014)$, Warszawa $(-0,006)$ oraz Wrocław $(-0,003)$.

Podobna sytuacja dotyczy drugiego analizowanego obszaru (rynek pracy), w ramach którego do grupy miast charakteryzujących się poprawą w stosunku do zmieniającego się maksymalnego poziomu w latach 2002-2011 (dodatnie średnie tempo zmian zmiennej syntetycznej) zakwalifikowano również 28 z 36 miast średniej wielkości (ok. 78\%) oraz aż 20 z 23 miast dużych (ok. 87\%). Ujemne tempo zmian zaobserwowano w przypadku następujących miast średniej wielkości: Dąbrowa Górnicza (-0,0395), Mysłowice $(-0,0226)$, Nowy Sącz $(-0,0225)$, Chełm $(-0,0101)$, Siemianowice Śląskie $(-0,0053)$, Legnica $(-0,0047)$, Ostrołęka $(-0,0044)$, Piotrków Trybunalski $(-0,0039)$, Leszno $(-0,0036)$, Konin $(-0,0004)$, Zielona Góra $(-0,003)$ oraz jedynie w przypadku trzech dużych miast: Zabrze $(-0,0063)$, Rzeszów $(-0,0052)$, Białystok $(-0,0037)$.

Średnie arytmetyczne dla pięciu kolejnych obszarów (wynagrodzenia i dochody ludności, warunki i bezpieczeństwo pracy, oświata i edukacja, kultura i czas wolny, komunikacja i łączność) w przypadku miast średniej wielkości mają wartości ujemne. Natomiast w przypadku dużych miast ujemne wartości średniego tempa zmian odnotowano jedynie w przypadku dwóch obszarów (wynagrodzenia i dochody ludności oraz warunki mieszkaniowe). Wartości ujemne w przypadku dużych miast dotyczą głównie lat wcześniejszych, w ostatnich dwóch latach uzyskano w większości przypadków wartości dodatnie, co wskazuje na zmniejszanie się dystansu w ostatnich dwóch latach w stosunku do najlepszego miasta. Natomiast w przypadku miast średnich są z reguły charakterystyczne dla całego analizowanego przedziału czasu. Oznacza to, że w całym analizowanym okresie rosła liczba miast średnich, których względna odległość od najlepszego miasta zwiększała się. Wskazuje to na postępujące pogarszanie się poziomu uzyskanego dla 
poszczególnych obszarów w stosunku do maksymalnego poziomu, jaki można było uzyskać.

Na rysunkach 1-2 przedstawiono wartości średniego tempa zmian zarówno dla miast średniej wielkości, jak i dużych dla ostatniego analizowanego obszaru: „komunikacja i łączność”.

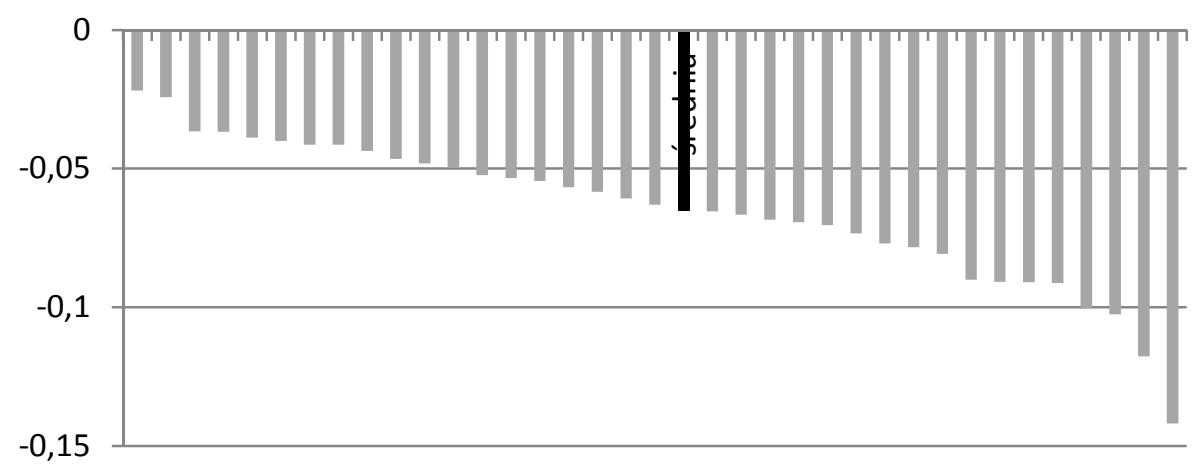

Rysunek 1. Średnie tempo zmian w obszarze „komunikacji i łączności” dla miast średniej wielkości w latach 2002-2011

Źródło: opracowanie własne.

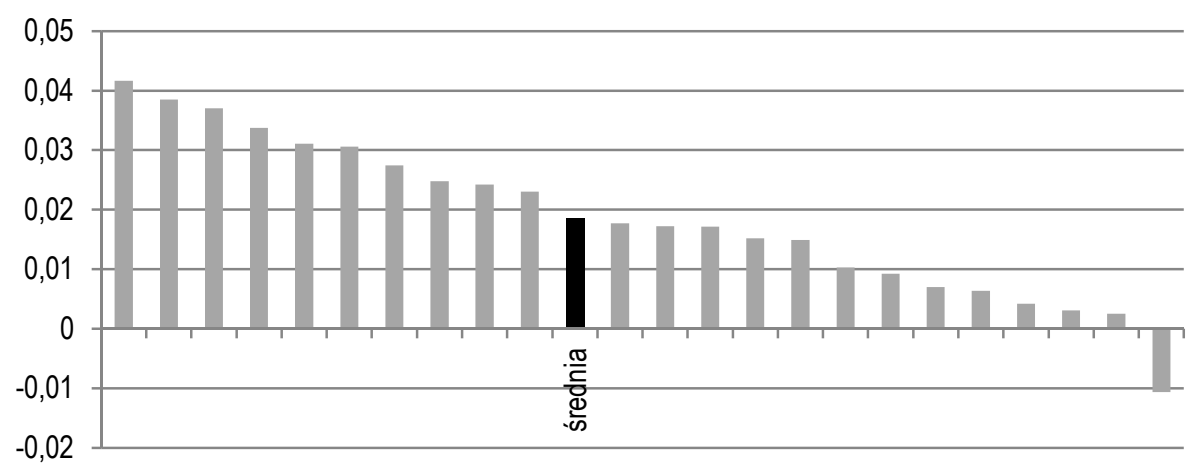

Rysunek 2. Średnie tempo zmian w obszarze „komunikacji i łączności” dla miast dużych w latach 2002-2011

Źródło: opracowanie własne.

Uzyskane dla tego obszaru wartości mierników potwierdzają znaczne zróżnicowaniu średniego tempa zmian analizowanych miast. Na zróżnicowanie w tym obszarze wskazują np. znaczne różnice pomiędzy wartością 
Tabela 2. Charakterystyki opisowe zmiennych syntetycznych wyznaczonych dla dużych miast oraz miast średniej wielkości

\begin{tabular}{|c|c|c|c|c|c|c|c|}
\hline \multirow{2}{*}{ Rok } & \multicolumn{7}{|c|}{ Miasta średniej wielkości } \\
\hline & $Z_{1 t}$ & $Z_{2 t}$ & $Z_{3 t}$ & $Z_{4 t}$ & $Z_{5 t}$ & $Z_{6 t}$ & $Z_{7 t}$ \\
\hline 2002 & 0,586 & 0,590 & 0,434 & 0,847 & 0,842 & 0,712 & 0,535 \\
\hline 2003 & 0,657 & 0,703 & 0,388 & 0,848 & 0,839 & 0,711 & 0,533 \\
\hline 2004 & 0,624 & 0,664 & 0,359 & 0,849 & 0,842 & 0,706 & 0,431 \\
\hline 2005 & 0,629 & 0,682 & 0,377 & 0,834 & 0,853 & 0,708 & 0,506 \\
\hline 2006 & 0,644 & 0,668 & 0,421 & 0,847 & 0,804 & 0,704 & 0,513 \\
\hline 2007 & 0,654 & 0,679 & 0,409 & 0,846 & 0,802 & 0,648 & 0,416 \\
\hline 2008 & 0,640 & 0,686 & 0,416 & 0,847 & 0,815 & 0,618 & 0,421 \\
\hline 2009 & 0,649 & 0,679 & 0,407 & 0,845 & 0,811 & 0,554 & 0,483 \\
\hline 2010 & 0,656 & 0,675 & 0,409 & 0,847 & 0,798 & 0,551 & 0,443 \\
\hline 2011 & 0,652 & 0,697 & 0,357 & 0,845 & 0,811 & 0,581 & 0,414 \\
\hline \multicolumn{8}{|c|}{ Charakterystyki opisowe } \\
\hline Średnia arytmetyczna & 0,639 & 0,672 & 0,398 & 0,845 & 0,822 & 0,649 & 0,469 \\
\hline Odchylenie standardowe & 0,022 & 0,031 & 0,026 & 0,004 & 0,020 & 0,068 & 0,050 \\
\hline Mediana & 0,646 & 0,679 & 0,408 & 0,847 & 0,813 & 0,676 & 0,463 \\
\hline Maksimum & 0,657 & 0,590 & 0,357 & 0,834 & 0,798 & 0,551 & 0,414 \\
\hline Minimum & 0,586 & 0,703 & 0,434 & 0,849 & 0,853 & 0,712 & 0,535 \\
\hline \multicolumn{8}{|c|}{ Miasta duże } \\
\hline Rok & $Z_{1 t^{\prime}}$ & $Z_{2 t} t^{\prime}$ & $Z_{3 i} t^{\prime}$ & $Z_{4 t^{\prime}}$ & $Z_{5 t^{\prime}}$ & $Z_{6 t} t^{\prime}$ & $Z_{7 t^{\prime}}$ \\
\hline 2002 & 0,671 & 0,644 & 0,486 & 0,894 & 0,747 & 0,608 & 0,451 \\
\hline 2003 & 0,704 & 0,685 & 0,449 & 0,893 & 0,748 & 0,591 & 0,471 \\
\hline 2004 & 0,692 & 0,707 & 0,436 & 0,892 & 0,743 & 0,571 & 0,493 \\
\hline 2005 & 0,706 & 0,709 & 0,434 & 0,890 & 0,753 & 0,557 & 0,558 \\
\hline 2006 & 0,662 & 0,742 & 0,433 & 0,889 & 0,753 & 0,546 & 0,595 \\
\hline 2007 & 0,666 & 0,761 & 0,424 & 0,886 & 0,798 & 0,543 & 0,550 \\
\hline 2008 & 0,668 & 0,734 & 0,421 & 0,885 & 0,756 & 0,548 & 0,610 \\
\hline 2009 & 0,693 & 0,776 & 0,379 & 0,883 & 0,773 & 0,589 & 0,638 \\
\hline 2010 & 0,705 & 0,760 & 0,414 & 0,882 & 0,765 & 0,613 & 0,626 \\
\hline 2011 & 0,703 & 0,784 & 0,429 & 0,881 & 0,751 & 0,616 & 0,617 \\
\hline \multicolumn{8}{|c|}{ Charakterystyki opisowe } \\
\hline Średnia arytmetyczna & 0,687 & 0,730 & 0,430 & 0,887 & 0,759 & 0,578 & 0,561 \\
\hline Odchylenie standardowe & 0,018 & 0,044 & 0,027 & 0,005 & 0,016 & 0,029 & 0,068 \\
\hline Mediana & 0,693 & 0,738 & 0,431 & 0,888 & 0,753 & 0,580 & 0,577 \\
\hline Maksimum & 0,662 & 0,644 & 0,379 & 0,881 & 0,743 & 0,543 & 0,451 \\
\hline Minimum & 0,706 & 0,784 & 0,486 & 0,894 & 0,798 & 0,616 & 0,638 \\
\hline
\end{tabular}

Źródło: obliczenia własne.

najmniejszą i medianą oraz medianą i wartością największą. Różnica pomiędzy średnim tempem zmian np. w przypadku miasta średniej wielkości, dla którego dystans w stosunku do najlepszego miasta w ostatnim analizowanym obszarze „komunikacja i łączność” zmniejszył się najbardziej, a miastem, dla którego dystans ten zwiększył się najbardziej, wynosi 0,0356. Wartość ta 
jest prawie 3-krotnie większa od odchylenia standardowego, co świadczy o dużym zróżnicowaniu dynamiki analizowanych miast.

W kolejnym etapie badania, na podstawie otrzymanych wartości badanych zmiennych syntetycznych opisujących siedem obszarów analizowanych mierników oszacowano funkcje trendu, które można następnie wykorzystać do wyznaczania prognoz przez ekstrapolację trendów. W tabeli 2 zamieszczono wartości zmiennych syntetycznych oraz ich charakterystyki opisowe: $Z_{q t}(q=1, \ldots, 7 ; t=1, \ldots 10)$ dla miast średniej wielkości oraz $Z_{q t}$, $(q=1, \ldots, 7 ; t=1, \ldots 10)$ dla dużych miast w latach 2002-2011. W tabeli tej zamieszczono również charakterystyki opisowe badanych zmiennych.

Wartości zmiennych syntetycznych dotyczące siedmiu analizowanych obszarów obejmujących mierniki wyznaczone dla 36 miast średniej wielkości oraz 23 dużych miast wykorzystano do oszacowania funkcji trendów, które przedstawiono w tabeli 3.

Tabela 3. Funkcje trendów dla zmiennych syntetycznych opisujących siedem badanych obszarów w latach 2002-2011

\begin{tabular}{|c|c|c|c|}
\hline \multirow[b]{2}{*}{ Zmienna syntetyczna } & \multicolumn{3}{|c|}{ Miasta średniej wielkości } \\
\hline & & $\begin{array}{c}\text { Współczynnik } \\
\text { determinacji }\left(\mathrm{R}^{2}\right)\end{array}$ & $\begin{array}{l}\text { Współczynnik } \\
\text { zmienności }\left(V_{s}\right)\end{array}$ \\
\hline$Z_{1 \mathrm{t}}$ & $\hat{z}_{1 t}=0,6389$ & - & 0,0217 \\
\hline$Z_{2 t}$ & $\hat{z}_{2 t}=0,6723$ & - & 0,0312 \\
\hline$Z_{3 t}(2004-2011)$ & $\hat{z}_{3 t}=-\underset{(-5,3579)}{0,0049 t^{2}}+\underset{(5,3864)}{0,0452 t}+\underset{(19,15365)}{0,3152}$ & 0,8539 & 0,0297 \\
\hline$Z_{4 t}$ & $\hat{z}_{4 t}=0,8453$ & - & 0,0044 \\
\hline$Z_{5 t}$ & $\hat{z}_{5 t}=1,0305$ & - & 0,0305 \\
\hline$Z_{6 t}$ & $\hat{z}_{6 t}=-\underset{(-1,0914)}{-0,0014 t^{2}}-\underset{(-1,3568)}{0,0052} t+\underset{(21,1683)}{0,7312}$ & 0,8552 & 0,0452 \\
\hline$Z_{7 t}$ & $\hat{z}_{7 t}=0,4695$ & - & 0,0497 \\
\hline \multicolumn{4}{|c|}{ Miasta duże } \\
\hline$Z_{1 t}^{\prime}$ & $\hat{z}_{1 t}=0,6869$ & - & 0,0266 \\
\hline$Z_{2 t}^{\prime}$ & $\hat{z}_{2 t}=-\underset{(-2,2071)}{-0,0014 t^{2}}+\underset{(4,0747)}{0,0286 t-}-\underset{(37,2775)}{0,6259}$ & 0,9182 & 0,0195 \\
\hline$Z_{3 t} t^{\prime}$ & 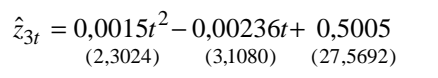 & 0,7423 & 0,0359 \\
\hline$Z_{4} t^{\prime}$ & $\hat{z}_{4 t}=\underset{(1,9646)}{-0,0029 t^{2}-}-\underset{(-6,7301)}{0,0015} t+\underset{(1647,7880)}{0,8960}$ & 0,9926 & 0,0005 \\
\hline$Z_{5 t^{\prime}}$ & $\hat{z}_{5 t}=0,7587$ & - & 0,0215 \\
\hline$Z_{66} t^{\prime}$ & $\hat{z}_{6 t}=\underset{(7,5491)}{0,0350 t^{2}-0,00368 t} \quad(-7,0318) \quad \underset{(51,5812)}{0,6457}$ & 0,8941 & 0,0184 \\
\hline$Z_{7 t}^{\prime}$ & 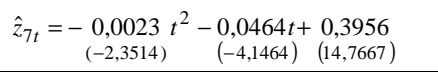 & 0,9136 & 0,0406 \\
\hline
\end{tabular}

Źródło: obliczenia własne. 
W prezentowanej tabeli oprócz wartości statystyki $t$-Studenta znajdujących się pod ocenami parametrów, zamieszczono również wartości współczynnika determinacji $\left(\mathrm{R}^{2}\right)$ oraz współczynnika zmienności $\left(\mathrm{V}_{\mathrm{s}}\right)$.

W przypadku zmiennej syntetycznej opisującej obszar ,wynagrodzenia i dochody ludności" $\left(Z_{3 t}\right)$ ze względu na występowanie obserwacji nietypowych pominięto dwie pierwsze wartości odstające. Oszacowania modelu trendu dla tego obszaru dokonano dla lat 2004-2011. Informację o okresie, dla którego oszacowano funkcję trendu, podano obok symbolu zmiennej.

W przypadku miast średniej wielkości udało się oszacować modele trendu jedynie dla dwóch obszarów: ,wynagrodzenia i dochody ludności” oraz „kultura i czas wolny”. Modele te miały postać wielomianu stopnia drugiego. W związku z tym, że wartości oszacowań parametrów przy najwyższej potędze są ujemne, można przyjąć, że średni poziom życia, wyznaczony za pomocą tych dwóch grup mierników dla tych obszarów, w stosunku do wartości maksymalnych, które można było osiągnąć w danym okresie, od pewnego momentu malał.

Równania trendu wyznaczone dla tych obszarów przedstawione zostały na rysunkach 4-5.

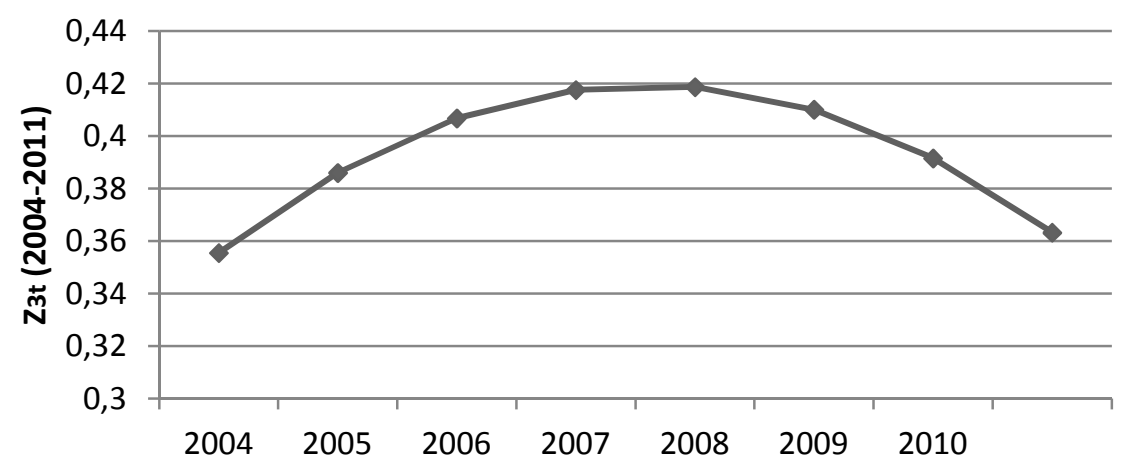

Rysunek 4. Funkcja trendu wyznaczona dla obszaru „wynagrodzenia i dochody ludności” dla miast średniej wielkości w latach 2002-2011

Źródło: opracowanie własne.

W przypadku pozostałych rozpatrywanych obszarów uzyskane modele trendu (liniowego i parabolicznego) charakteryzowały się bardzo niską oceną współczynnika determinacji, a parametry modelu były nieistotne statystycznie. W związku z tym przyjęto, że trendem opisującym pozostałe obszary będą stałe równe średniej arytmetycznej z wartości syntetycznej dla danej dziedziny. Oznacza to, że w rozpatrywanym okresie poziom życia 


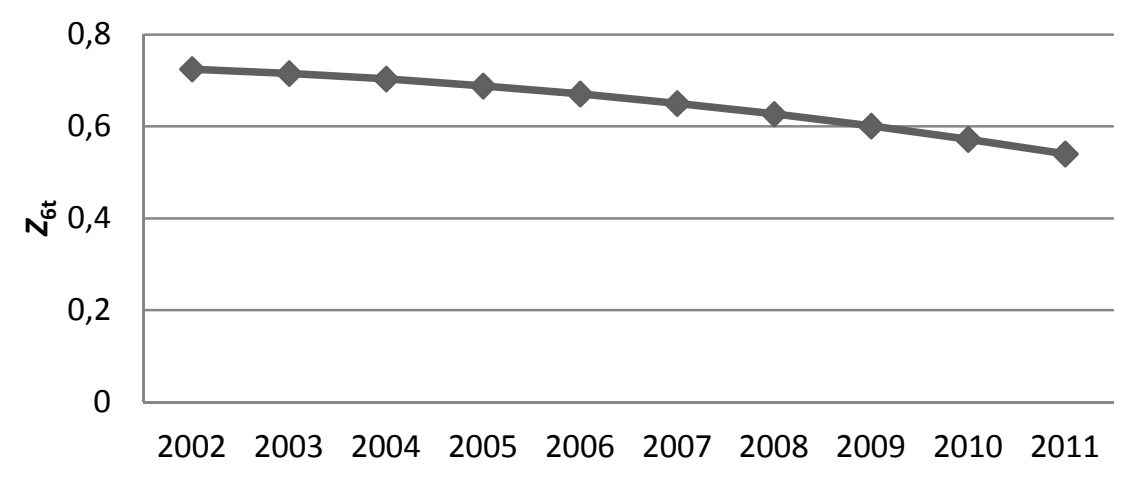

Rysunek 5. Funkcja trendu wyznaczona dla obszaru „kultura i czas wolny” dla miast średniej wielkości w latach 2002-2011

Źródło: opracowanie własne.

mierzony tymi miernikami pozostawał niezmieniony w stosunku do wartości maksymalnej w danym okresie.

Natomiast w przypadku zmiennych dotyczących dużych miast nie udało się oszacować modeli trendu jedynie dla dwóch obszarów: „ochrona zdrowia” $\left(Z_{1 t}\right)$ i „oświata i edukacja” $\left(Z_{5 t}\right)$. W związku z tym przyjęto, podobnie jak w przypadku miast średniej wielkości, że trendem opisującym te obszary będą stałe równe średniej arytmetycznej z wartości syntetycznej dla danego obszaru. Oznacza to, że w rozpatrywanym okresie poziom życia mierzony tymi miernikami pozostawał niezmieniony w stosunku do wartości maksymalnej w danym okresie. W przypadku pozostałych rozpatrywanych obszarów oszacowane modele miały postać wielomianu stopnia drugiego. Ujemne wartości oszacowań parametrów przy najwyższej potędze uzyskano w przypadku obszarów: „rynek pracy”, „warunki i bezpieczeństwo pracy”, „,warunki mieszkaniowe”, „komunikacja i łączność”. Oznacza to, że średni poziom życia, wyznaczony dla tych obszarów, w stosunku do wartości maksymalnych, które można było osiągnąć w danym okresie, od pewnego momentu malał. Natomiast w przypadku obszarów opisujących „wynagrodzenia i dochody ludności” i „kulturę i czas wolny” wartości oszacowań parametrów przy najwyższej potędze są dodatnie. Oznacza to, że średni poziom życia, wyznaczony dla tych obszarów, w stosunku do wartości maksymalnych, które można było osiągnąć w danym okresie, od pewnego momentu wzrastał. Równania trendu wyznaczone dla tych obszarów przedstawione zostały na rysunkach 6-7. 


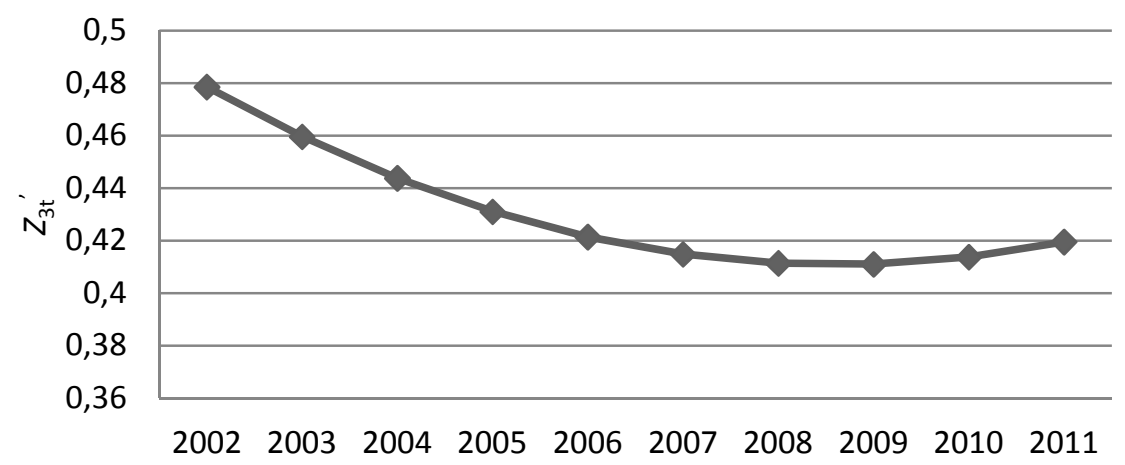

Rysunek 6. Funkcja trendu wyznaczona dla obszaru ,wynagrodzenia i dochody ludności” dla dużych miast w latach 2002-2011

Źródło: opracowanie własne.

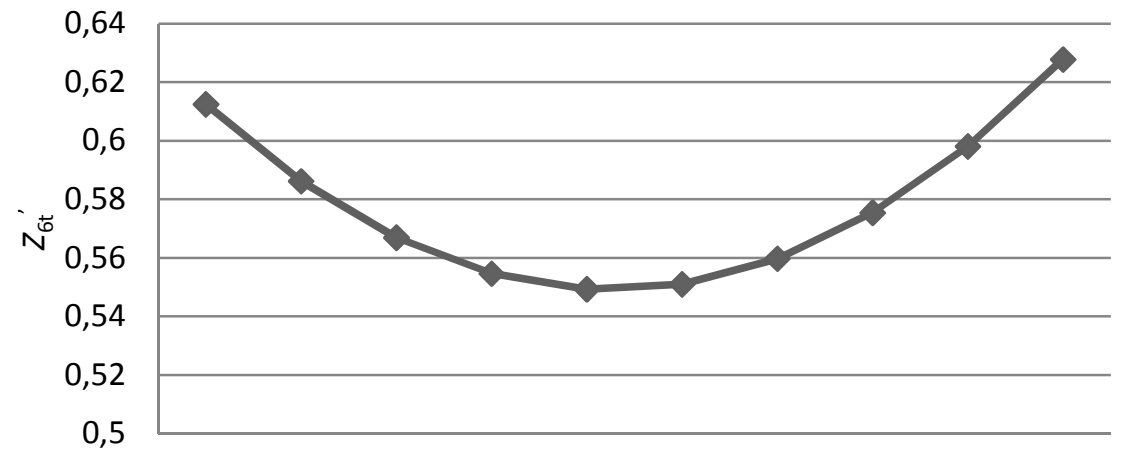

Rysunek 7. Funkcja trendu wyznaczona dla obszaru „kultura i czas wolny” dla dużych miast w latach 2002-2011

Źródło: opracowanie własne.

\section{PODSUMOWANIE}

Przedstawione $\mathrm{w}$ pracy rozważania dotyczące analizy dynamicznej zmiennych syntetycznych opisujących siedem obszarów poziomu życia ludności miast średniej wielkości (od 50 do 150 tys. mieszkańców) oraz ludności dużych miast (powyżej 150 tys. mieszkańców) mogą stanowić podstawę do wyznaczenia (przez ekstrapolację trendów zaobserwowanych w przeszło- 
ści) ścieżek rozwoju poziomu życia ludności miast na kolejne lata. Na podstawie oszacowanych zmiennych syntetycznych opisujących różne obszary poziomu życia oszacowane zostały modele trendu, przy czym w przypadku miast średniej wielkości udało się oszacować modele trendu jedynie dla dwóch obszarów: „wynagrodzenia i dochody ludności” oraz „kultura i czas wolny". Modele te miały postać wielomianu stopnia drugiego, przy czym ujemne wartości oszacowań parametrów przy najwyższej potędze wskazywały, że średni poziom życia, wyznaczony dla tych obszarów, w stosunku do wartości maksymalnych, które można było osiągnąć w danym okresie, od pewnego momentu malał.

Natomiast w przypadku dużych miast udało się oszacować modele trendu dla pięciu spośród siedmiu analizowanych obszarów, są to: „rynek pracy”, „warunki i bezpieczeństwo pracy”, „wynagrodzenia i dochody ludności”, „warunki mieszkaniowe”, „kultura i czas wolny”, „komunikacja i łączność". Wszystkie te modele miały również postać wielomianu stopnia drugiego. W przeciwieństwie do wyników uzyskanych w przypadku miast średnich w obszarze obejmującym „wynagrodzenia i dochody ludności” uzyskano dodatnią wartość oszacowania parametru przy najwyższej potędze, co wskazuje na wzrost od pewnego momentu w stosunku do wartości maksymalnej, którą można było osiągnąć w danym okresie. W przypadku obszarów, dla których nie udało się oszacować modeli trendu, przyjęto, podobnie jak w przypadku miast średnich, że trendem opisującym te dziedziny będą stałe równe średniej arytmetycznej z wartości syntetycznych dla danego obszaru.

Przedstawiony w pracy przebieg badania ma jednak ograniczenia wynikające z niemożliwości przyjęcia jako wzorca obiektu pochodzącego spoza badanego zbioru. Jak wykazano w pracy Nermend (2008), w przypadku porównywania poziomu rozwoju $\mathrm{np}$. miast polskich $\mathrm{z}$ odpowiadającymi im jednostkami terytorialnymi najlepiej rozwiniętego państwa Unii Europejskiej może pojawić się sytuacja zniekształcenia wyników np. na skutek odstawania współrzędnych obiektów. Sytuacja tego typu może oznaczać, że po standaryzacji maksymalna (bądź minimalna) wartość takiej zmiennej może być nawet 10-krotnie większa niż wartości maksymalne (minimalne) innych zmiennych. W takich sytuacjach jednym z rozwiązań może być np. wykorzystanie rachunku wektorowego, który umożliwia określenie kierunków w przestrzeni i ich porównywanie. 


\section{LITERATURA}

Bąk I. (2008), The Application of the Multidimentional Scalling to the Segmentation of the Pensioners Outgoing Tourism in Terms of the Enviroment Quality, „Polish Journal of Environmental Studies", 25-47.

Berry B. J. L. (1981), Comparative urbanization: Divergent patos in the twentieh century, St. Martin Press, New York.

Campbell A. (1976), Subjective Measures of Well-being, „American Psychologist”, 2, 55-78, DOI: http://dx.doi.org/10.1037/0003-066X.31.2.117.

Cheba K. (2010), Analysis of development trends of standard of living for medium-sized cities in Poland, [w:] Dittmann P. (red.), Forecasting, UE Wrocław, 30-41.

Geröhazi E., Hegedus J. (2011), The impact of European demographic trends on regional and urban development. Synthesis report, Metropolitan Research Institute, Budapest.

Grabiński T., Wydymus S., Zeliaś A. (1983), Metody prognozowania rozwoju społeczno-gospodarczego, AE w Krakowie, Kraków.

Hellwig Z. (1981), Wielowymiarowa analiza porównawcza i jej zastosowanie $w$ badaniach wielocechowych obiektów gospodarczychi, PWE, Warszawa.

Herbst M. (2009), Tworzenie i absorpcja kapitału ludzkiego w polskich miastach akademickich w kontekście realizacji narodowej strategii spójności, Ministerstwo Rozwoju Regionalnego, Warszawa.

Hooley G. J. (1980), Multidimensional Scaling of Consumer Perceptions and Preferences, „European Journal of Marketing”, 14(7), 436-448, DOI: http://dx.doi.org/10.1108/EUM0000000004919.

Jajuga K. (1993), Statystyczna analiza wielowymiarowa, PWN, Warszawa.

Mallach A. (2010), Facing the Urban Challenges. The Federal Government and America's Older Distressed Cities, Brookings Institution's Metropolitan Policy Program, Washington.

Nermend K. (2008), Rachunek wektorowy $w$ analizie rozwoju regionalnego, „Rozprawy i Studia", 694.

Nowak E. (1990), Metody taksonomiczne w klasyfikacji obiektów spoteczno-gospodarczych, PWE, Warszawa.

Ostasiewicz W. (2004), Ocena i analiza jakości życia, AE, Wrocław.

Parysek J. (2005), Miasta polskie na przetomie XX i XXI wieku. Rozwój i przeksztatcenia strukturalne, Bogucki Wydawnictwo Naukowe, Poznań.

Walesiak M. (1990), Syntetyczne badania porównawcze w świetle teorii pomiaru, „Przegląd Statystyczny", 1-2.

Wojciechowski P. (2013), Zarządzanie rozwojem miast o zmniejszającej się liczbie mieszkańców (w kontekście perspektywy finansowej 2014-2020), Kancelaria Senatu RP, Warszawa.

Zahra S. A. (1993), Environment, corporate entrepreneurship, and financial performance: A taxonomic approach, ,Journal of Business Venturing”, 8, 319-340, DOI: http://dx.doi.org/-10.1016/0883-9026(93)90003-N.

Zeliaś A. (red.) (1991), Ekonometria przestrzenna, PWE, Warszawa.

Zeliaś A. (red.) (2000), Taksonomiczna analiza przestrzennego zróżnicowania poziomu życia $w$ Polsce $w$ ujęciu dynamicznym, AE ,Kraków.

Zeliaś A. (red.) (2004), Poziom życia $w$ Polsce $i$ w krajach Unii Europejskiej, PWE, Warszawa. 


\title{
THE SPATIAL-TEMPORARY MODELING OF STANDARD OF LIVING FOR CITIES RESIDENTS IN POLAND
}

\begin{abstract}
A b s t r a c t. There is scant information on the spatial differentiation of the standard of living in cities. This work has therefore attempted to analyze the spatial differentiation of the standard of living of the populations of towns in a dynamic approach, on the basis of the data from the years 2002-2011. Including time in the spatial differentiation of the standard of living enabled to select the towns in which the improvement in the standard of living is observable, the towns with the steady standard and those in which the standard of living is deteriorating, thanks to the possibility of using the methods of time series analysis.
\end{abstract}

K e y w o r d s: spatial-temporary modeling, dynamic analysis, cities development. 